\title{
Raising the Value of Local Wisdom "Ro'a Dun Kare Taden" in Sikka Regency as a Learning Material for Students in Elementary School
}

\author{
Marianus Yufrinalis ${ }^{1}$ and Egidius Dewa ${ }^{2}$ \\ \{andryjfr88@gmail.com ${ }^{1}$, egidiusdewa@gmail.com $\left.{ }^{2}\right\}$ \\ Primary Education Department of Nusa Nipa Indonesia University, Provinsi NTT ${ }^{1}$, Physics Education \\ Department of Widya Mandira University Kupang, Provinsi NTT ${ }^{2}$
}

\begin{abstract}
The world today is experiencing a very crucial impact of global warming. During the last century or so, the earth's temperature has increased quite significantly with an average temperature ranging from $0.74 \pm 0.18^{\circ} \mathrm{C}$. The negative impact of prolonged global warming has prompted humans to carry out campaigns to save the environment, including reducing greenhouse gas emissions, eradicating plastic waste, and returning to local wisdom in managing natural resources. The local wisdom of the Sikka people, Ro'a Dun Kare Taden is one of the ancestral legacies of the Sikka community, which invites everyone to keep the forest as the lungs of the world. The purpose of this research is to raise the traditions and values of local wisdom Ro'a Dun Kare Taden in the Sikka community as a learning resource for elementary school students, especially to provide a foundation for understanding the importance of preserving the forest environment as the lungs of the world. The research method used is descriptive qualitative method using data collection techniques from the results of observations, interviews and documentation studies. The results showed that learning the introduction of the natural environment and its preservation efforts by promoting local wisdom values such as Ro'a Dun Kare Taden had a positive impact on students' learning motivation and their love for the environment.
\end{abstract}

Keywords: Local Wisdom; Learning Material; Students

\section{Introduction}

According to RI Law Number 32 of 2009, the living environment is a spatial unit with all objects, forces, conditions and living things, including humans and their behavior, which affect nature itself, the continuity of life, and the welfare of humans and other living creatures. The environment is very influential for human life because humans and the environment interact with each other (Mukhtar, et.al. 2010: 133). The environment can change its function due to various factors, one of which is the global era. The impact of environmental problems can be felt by all inhabitants of the earth with natural phenomena that show irregularities.

Environmental damage is something that is difficult to separate in people's lives. The need for land causes humans to deforest forest areas for agricultural and residential purposes (Syaprillah \& Sapriani, 2014: 598). Community life, namely human activities, is the cause of catastrophic events and environmental damage. These activities or activities illustrate that human have a low level of concern for environmental sustainability. 
Sriyanto (2007) explains that environmental damage occurs everywhere due to people who do not care, have minimal awareness and the law does not function optimally. Minimal awareness of environmental preservation can be changed for the better through environmental education which is applied to the community and school environment. Environmental education that is real in preserving the environment is obtained by students through the life around them. Surrounding life that can support environmental preservation is through the application of local wisdom values. Local wisdom is the values or norms that are valid and even believed in a society to this day (Gunawan, 2014). Values or norms whose truth is believed so that they become role models for society in their daily behavior and which are properly implemented will have a high awareness in protecting their environment.

Environmental problems are closely related to the application of local wisdom values in a community group related to environmental regulation and management. It can be seen that local wisdom has played a role in preserving the environment before environmental movements emerged. Wibowo et al. (2012) revealed that the existence of myths, rituals, and sublime traditions that are closely related to nature are able to regulate society in such a way as to relate to the surrounding environment. Local wisdom is a characteristic of a certain area or region that has cultural values, developing in the local sphere from generation to generation (Sartini, 2004). Research by Mansur (2018) confirms that the local wisdom of kemalik is the prohibition of entering the customary forest of Mount Kiyangan carelessly, which if violated will result in disaster or disturbance in the future. Local wisdom can be understood as local (local) ideas that are wise, full of wisdom, of good value, which are embedded and followed by members of the community.

Local wisdom that teaches about the preservation of the natural environment is widely spread in areas where primordial culture is still strong. As discussed in this paper, local wisdom that grows and is implemented in the Waigete District, Sikka Regency, East Nusa Tenggara is knowledge that has been passed down from generation to generation. The big role of local wisdom is used in preserving the environment which is applied through education in the community and in elementary schools. The use of local wisdom values must be in accordance with the characteristics of the local area.

Waigete is one of the districts in Sikka Regency, East Nusa Tenggara which consists of 9 villages, namely Aibura, Egon, Hoder, Nangatobong, Pogon, Runut, Wairbleler, Wairterang and Watudiran Villages. Most of the population in this area are indigenous to the Flores area. The development of the modern society's thinking system in the Waigete sub-district has an impact on the polarization of community work, thereby reducing the respect of the younger generation for their traditional knowledge. The rapid adoption of knowledge and culture in modern society has resulted in the dislocation of the traditional knowledge inheritance system. The dislocation of traditional knowledge and the destruction of its habitat has created various environmental crises that must be resolved.

The traditional knowledge of local wisdom possessed by each ethnic community in Sikka Regency, especially in Waigete District, needs to be documented through the application of local wisdom values to the community and schools so that it is not lost. Local wisdom has wise values, full of wisdom and good value and is integrated into subjects in school. Learning local wisdom values through informal education is a value internalization process that runs without design and runs spontaneously (Wardhani, 2013). The results of learning the values of local wisdom through informal education can actually improve human character or behavior so that it can be used as a strengthening of the nation's character. 
In Afandi's view (2013) environmental education is an effort to preserve the environment by teaching it formally in schools. Environmental education is not an independent field of study. However, it can be integrated into a field of study at school.

\section{Local Wisdom Ro'A Dun, Kare Taden in Sikka}

Local wisdom is a characteristic of a certain area or region that has cultural values, developing in the local scope from generation to generation (Sartini, 2004). Local wisdom can be understood as local ideas that are wise, full of wisdom, of good value, which are embedded and followed by members of the community. According to Kasa (2011), explaining that the important of local wisdom must also be considered as one of supporting efforts so that a decreasingly natural environment. This shows that the importance of local wisdom must also be considered as one of the supporters of environmental efforts that are decreasing naturally, therefore it is necessary to apply environmental preservation based on local wisdom to prevent the loss of local wisdom of an area. Local wisdom as one of the things that needs to be preserved, means that it needs to be preserved, protected and preserved so that it does not become extinct.

The existence of humans from the beginning is able to develop and adapt to the natural environment around them, because humans have a system of reason and an instinctual system that is capable of capturing natural phenomena and responding to them adaptively so as to create culture as an adaptation system that they create in relation to maintaining the existence of a relationship with their natural surroundings (Daeng, 2008). Samosir (2013) explains that socio-cultural values include four factors: (1) values are an abstraction of one's personal experiences; (2) the values are always filled in and dynamic in nature; (3) values are not a concrete goal of behavior, but a criterion for choosing goals; and (4) values are things that are very important and not things that are taken lightly.

Keraf (2002) explains that local wisdom is all forms of knowledge, belief, understanding or insight as well as customs or ethics that guide human behavior in life in an ecological community. All forms of local wisdom are lived, practiced, taught and inherited from generation to generation as well as forming patterns of human behavior towards fellow humans, natural and occult. Local wisdom that emerges in a community group arises from a concern for the importance of preserving the environment for the sustainability of future generations (Pasya, 2007: 2). The emergence of concern for the environment or environmental ethics is seen as a cultural system that is sustainable and has high values so that it must continue to be carried out by a community group. As part of the cultural system, the values of local wisdom animate a code of conduct for the members of the culture who support it. The code of conduct is contained in the customs, norms, ethics, way of life, and community ideology (Daeng, 2008: 46).

At the level of local communities in Waigete District, there is local wisdom in relation to environmental protection and preservation efforts. Local wisdom is based on the fact that most people depend on farming and farming for their livelihoods, so that many customary rules are made to maintain the preservation of the natural environment, especially protected forests. This indicates that the interaction between humans living in the middle of the forest or around it with natural resources in the forest, needs to be regulated in such a way so that it does not adversely affect the ecosystem of the forest environment (Dako, et.al., 2019: 437). By continuing to maintain the preservation of protected forests, the Waigete people consider the sustainability and preservation of living things to be guaranteed, especially the availability of natural resources for the community and their future generations. 
According to Seti (2020), the fact that at the level of regulations or customary rules of the Waigete people, the maintenance and protection of protected forest ecosystems is known as "Ro'A Dun, Kare Taden". In this Waigete community customary forest protection regulation, there are 5 main prohibitions that must be obeyed by all indigenous groups in the Waigete District area, namely as follows:

a. Lian Poa, Wair Matan, namely prohibition of cutting down trees / plants around the spring area;

b. 'Reping Go'it, 'Raeng Ra'at, namely the prohibition of cutting down trees / plants around the cliff area to prevent landslides;

c. $\mathrm{Ai}$ 'Wau, Watu Narin, namely the prohibition of cutting down trees / plants in a place that functions as a place of rest and / or resting place;

d. Ro'a Dun, Kare Taden, namely appeals or invitations to carry out a selective cutting pattern and replant tree seedlings that have been cut down previously;

e. Siot Linok, Ogor Wokot, namely the prohibition of cutting down trees / plants in places specifically designated as places for defecating.

With the existence of five rules or restrictions that apply to community groups in Waigete District, the availability of protected forests and their preservation can be maintained to this day.

\section{Methodology}

The research method used by researchers in this study is a qualitative method with a descriptive analysis approach. The research method used is a qualitative method. "Methodology is the process, principles, and procedures that we use to approach problems and seek answers" (Mulyana, 2008: 145). According to Sugiyono (2007: 1), the qualitative research method is a study that is used to examine natural objects where the researcher is a key instrument, data collection techniques are carried out in combination, data analysis is inductive, and the results of qualitative research emphasize meaning rather than generalization.

The technique of collecting data in qualitative research is by making observations, interviews, and documentation studies. Observations made in this study are observations. Observations were made by means of non-participant observation of forest environmental conditions and socio-cultural situations in the local community. Interviews were conducted to determine to complete data and efforts to obtain accurate data and appropriate data sources. In this study, the authors interviewed 6 informants, consisting of traditional leaders, community leaders, cultural practitioner, school principals and elementary school teachers.

The author uses purposive sampling technique to determine the informants in this study. Purposive sampling technique is a way of determining informants by selecting informants according to the criteria and needs of the author in this study. In this study, the authors identified several key informants and additional informants with role descriptions as shown in the following table. 


\section{Result and Discussion}

Based on the results of previous documentary studies, observations and interviews, the authors found several important ideas related to efforts to revive the values of local wisdom regarding the philosophy of maintaining, protecting and preserving the forest environment as an ecosystem that should be maintained. In excerpts of several interviews conducted by previous authors, it was found that the views of traditional leaders and community leaders stated that the progress of human civilization had taken away some of the values of local wisdom related to the maintenance and preservation of protected forest areas as a buffer for the basic needs of the community.

Facts on the ground show that human greed for the fulfillment of their daily needs has led to massive forest encroachment activities that have disrupted the ecosystem structure which has been beneficial for the community. Illegal logging activities of protected forest areas for agricultural land clearing by local residents have affected the balance of the forest environment itself. Most of the forest area has become deforested, the loss of clean water sources, the extinction of flora and fauna, so that the diversity of ecosystems is also lost. Prolonged drought also exacerbates the condition of the forest environment which no longer provides comfort and availability of natural resources for the community.

VS (2020), one of the customary leaders and chairperson of the customary community group managing community forests, in his explanation gave a clear picture of the bad impact of forest encroachment which violently contradicts the local wisdom philosophy of Ro'A Dun, Kare Taden.

"In 2000, we started a small community under the umbrella of the indigenous forest management group in the Egon Ili Medo area. Our customary institution is called Tara Gahar Tajo Mosan, which is currently located in Rubit Village, Hewokloang District. Of course, this customary institution does not exist on the basis of the interests of certain groups, but we see that there needs to be a customary institution that takes part in maintaining the sustainability of the regional forest ecosystem or community forest while upholding the philosophy of Ro'A Dun, Kare Taden. This is not just a mere slogan, but represents the call and desire of the local community so that the forest continues to exist now and in the future. The existence of our customary institution not only claims ulayat land which is our management right, but also wants to apply this philosophy so that forests can last forever. Our children and grandchildren also live from these forest products."

In his further explanation, VS highlighted the behavior of people today who have ignored local wisdom values to maintain the sustainability of the forest environment ecosystem. In order to fulfill their daily needs, the communities living in the vicinity of protected forest areas have ignored the prohibitions and regulations from the government and customary institutions to be allowed to cultivate land that has become customary rights or tribal land that has been previously distributed.

"Recently I heard many reports related to forest encroachment activities by a group of irresponsible people. Why do I say irresponsible? Because the perpetrators of these forest encroachers know and want to carry out illegal activities, by clearing land in the forest area that is prohibited without paying attention to the further impact of their actions. Forest areas covered and prohibited from being explored as termed, Lian Poa, Wair Matan (spring area), Reping Go'it 'Raeng Ra'at (cliff edge area), Ai' Wau, Watu Narin (forest area as a rest area), Ro'A Dun, Kare Taden (appeal for selective cutting and replanting), as well as Siot Linok, Ogor Wokot (forest areas that have been deliberately left as a place for defecating and so on). 
The same thing was confirmed by another traditional leader, FP (2020). He repeatedly reminded people in forest areas not to move around the covered forest area, or even exploit it excessively for personal and family members' interests. In his presentation, Philip explained that the impact of illegal forest encroachment, cutting down trees with quality wood, has dragged several perpetrators to prison. Furthermore, it is believed, nature becomes angry because of greedy human actions, so that landslides and flash floods often occur unexpectedly. This is because the area on the slopes of the mountains around the protected forest has been converted by the community as plantation land.

"We often find certain groups or individuals carrying out illegal logging activities in protected forest areas. As traditional leaders, the impact of his actions is that we impose customary sanctions with the term Sube Ai, Nunga Tali, as part of the Sisa Soba ritual. This ritual requires forest encroachers to apologize to nature (forest) and is obliged to replant trees in areas that have been deforested. The sanctions are strict because they are carried out under customary oath. "

As in the author's observations in the field, the protected forest areas, the ecosystem buffer forests in the Egon Ilimedo area are in poor condition. Some areas that fall into the prohibited category and are not to be managed as land have instead turned into plantation areas. The boundary (Pal-32) as a forbidden forest area is currently the location of forest encroachment.
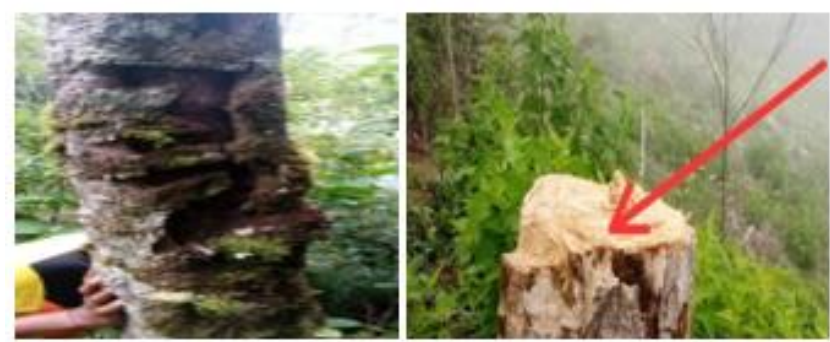

Fig 1. The tree dividing the Pal-32 area, which previously stood firmly, has been felled

Forest encroachment behavior has a wide impact on the balance of the environment around the forest area. Biodiversity and non-biological diversity, the wealth of flora and fauna, as well as the availability of clean water are reduced. In some areas, the problem of lack of clean water has become a crucial problem. To get clean water, people have to order water from coastal areas and cities which is transported via tank trucks at a quite expensive cost. In fact, because of the scarcity of water, traditional and community leaders took the initiative to carry out traditional rituals, Tolak Bala and Minta Hujan ceremonies.

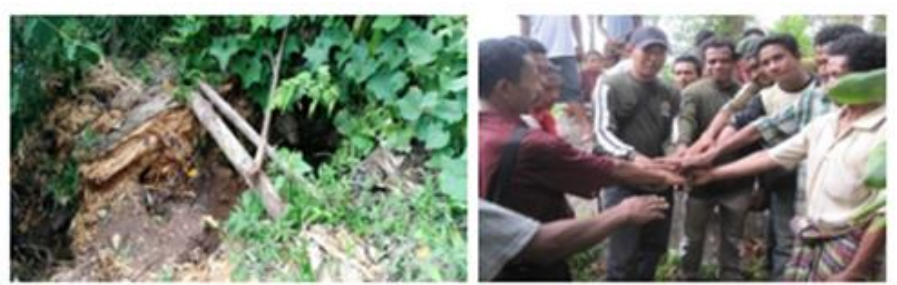

Fig 2. The condition of the springs that have been dry. The residents took the customary oath 
Whereas in certain village areas, where some of the residents are known to have carried out illegal forest encroachment activities, they will be given strict customary sanctions with the ritual of Sube Ai, Nunga Tali.

"In 2012, we arrested a number of residents who were cutting trees illegally. We also feel the impact of illegal logging. How difficult it is to get clean water even during the rainy season. So, we give customary fines, strict sanctions and oblige them to apologize to nature (forests) and replant land that is already deforested. " (LM, 2020).

On another occasion, the author also interviewed one of the community leaders in Rubit Village, Hewokloang District, namely YV (2020). In YV's presentation, it was explained that the practice of illegal logging and betraying the local wisdom inherited from our ancestors had been going on for a long time. Even the village apparatus (village government) is aware of the illegal activities. The village government has made a persuasive appeal, but this is ignored by the community group that encroaches on the illegal forest.

"The local government is aware of the illegal activity. However, it was left for so long even though there were warnings. Another reason, the family factor becomes an obstacle to law enforcement for violators of protected forest regulations. In a forest area near where we live, we work together to do reforestation by planting many trees that produce water sources. However, it is precisely in other subdistricts and villages that our reforestation activities are laughed at and disrespected."

The conditions described above also exacerbate the destruction of forests as a support for human life. The deforested forest area is strong evidence that the people in the local area have neglected the moral values and ecological responsibilities that are implied in the philosophy of Ro'A Dun, Kare Taden. This philosophy resonates only for a moment and does not last because of today's human greed. Of course, the opportunity to revive the spirit and local wisdom requires the responsibility of all parties, especially how to educate and teach the younger generation to love forest ecosystems.

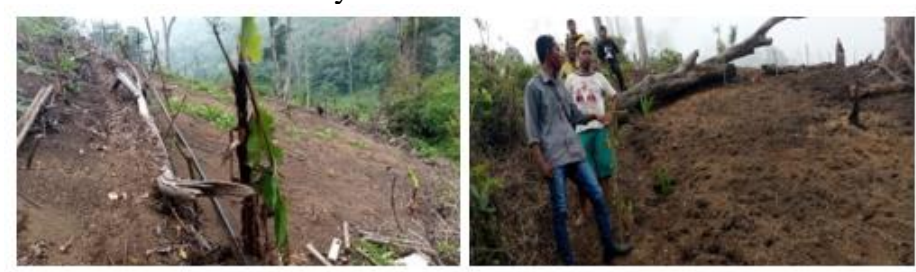

Fig 3. Protected forest areas that have been turned into vegetable plantations

\section{Discussion: Philosophy of Ro'A Dun Kare Taden in Elementary School Learning}

Talking about the application of local wisdom values to learning in elementary schools, in general, almost all subjects try to present values in the context of local culture that can be learned by students at school. Of course, the effort to present elements of local culture, including local wisdom values, in the context of student learning in elementary schools is not easy in practice. The progress of human civilization, which is marked by the globalization of science, technology and art, and supported by the globalization of complex and complex life styles, also contributes to the difficulty of students returning to access various local and national cultural treasures, especially living up to the values the value of local cultural wisdom in his everyday life. This condition is a serious challenge faced by educators today. Primordialism and local cultural hegemony are gripped by the ugly social, cultural, 
ideological, political and economic impacts that globally have permeated the present generation's personality.

In the previous review regarding efforts to revive the local cultural philosophy of Sikka in the realm of preservation, protection and maintenance of forest environmental ecosystems in a sustainable manner, the author also interviewed prominent educators (teachers) and school principals. These two elements are an inseparable part of the effort to inherit intellectual property, including the inheritance of local cultural wealth that is shared by certain groups of people. However, the role of teachers in schools is very important to help direct students' perceptions to something that is true, good and useful for their future interests. Several important notes emerged during interviews with additional informants in this study.

"As educators in elementary schools, we act as the first formal providers of knowledge at the basic education level. Of course, instead of ignoring the role of education at the kindergarten / early childhood level, students in elementary schools are more complex and are continuously given an understanding of certain topics or materials so that they are easily understood and digested properly. If I teach about character and love for local culture, I don't think it's just teaching in front of the class. However, it can organize creative activities that can arouse interest in the cultural values being taught. Talking about loving the forest environment and other ecosystems contained in it, several methods can be applied by a teacher. As an example; students can find out the benefits and urgency of protected forests by conducting direct lessons on the environment in question. This means that activities such as Nature Tourism, Natural Exploration, Study Tour, Reforestation, and School Roadshows can be a way out to leave certain themes related to efforts to conserve the forest environment in their respective areas. Even a teacher in his teaching does not forget to emphasize the values of local wisdom such as Ro'A Dun, Kare Taden in the material he teaches. " (JJ, 2020)

Based on the explanation above, the role of elementary schools at the lowest level of education (fundamental) has an important task to put fundamental values in learning on each material taught. The role of primary schools and teachers is seen as very important because they are the facilitators and guides for students in learning about the basic values of local wisdom and applying them in their daily lives. In addition, the implementation of the curriculum in elementary school is very flexible in terms of the existence of various themes that can be taught at the same time in every learning activity in the classroom. This condition is certainly ideal for accustoming students to cross-material learning and the teacher to act as a guide who can entrust the values of local wisdom.

"Learning in elementary schools within the current curriculum framework leads students to a comprehensive introduction and understanding across materials. Thematic learning that summarizes all the material in each learning activity is enough to help teachers identify, map, design, and explain the various topics being taught. Of course, the aspects of assessment that are expected to appear in every learning activity refer to the analysis of understanding the material, the achievement of problem-solving efforts, the rationalization of its application in everyday life. When talking about the application of Ro'A Dun Kare Taden's local wisdom in learning, it could be that in low-grade learning, one of the themes that is suitable for teaching this philosophy is the Environmental Theme. Even though the theme of Environment is generally taught, a teacher can discuss more specifically the importance of this local wisdom in building students' love for environmental conservation of protected forests. " (MA, 2020)

In learning in elementary schools, the environmental theme can be taken as a topic to teach students the importance of protecting the environment. For example, in class I Theme 6 subject matter specifically discusses a Clean, Healthy and Beautiful Environment. In Subtheme 1 My Home Environment and Sub-Theme 2 Environment Around My Home, teachers 
can include local wisdom materials about the environment in the presentation of material in class. In the core learning activities when the teacher explains the material to students, the teacher provides an explanation of the importance of preserving the surrounding environment in accordance with the values or spirit contained in social life. The scope of the explanation rests on efforts to keep the environment clean, preserve natural resources, and build a caring attitude towards the environment.

Regarding the values of local wisdom contained in the philosophy of Ro'A Dun Kare Taden, the teacher explained the importance of protecting forest resources, especially protected forests, as a support for human life. Students can be given an understanding of the importance of avoiding illegal logging behavior, which affects the carrying capacity of the environment and its sustainability in fulfilling the needs of human life. The attitudes and behaviors that can be raised in the spirit of Ro'A Dun Kare Taden are maintaining the availability of clean water and oxygen supply by not cutting trees illegally, replanting deforested forest areas, and striving for regular and responsible community forest management.

In the thematic learning in Class 3 Semester 2 with the theme of Protecting the Environment, the teacher can explain the material in general about the importance of preserving the environment. In the core learning activities, this material is explained by providing examples of the application of the spirit of environmental preservation based on local wisdom of Ro'A Dun Kare Taden. The teacher can design learning by raising the values of local wisdom in student group discussion activities. In groups, students can discuss to find the spirit and values that come from Ro'A Dun Kare Taden's local wisdom. Each group can present the results of their discussion and give examples on each form of local wisdom they choose. In addition, to increase students' understanding of the implementation of Ro'A Dun Kare Taden's local wisdom values in learning activities with the theme of Protecting the Environment, teachers can provide written tests and assignments to students to find additional information related to the implementation of Ro'A Dun Kare Taden's philosophy in social life.

Thus, it can be concluded that the role of basic education is not only a student's first stepping stone to get to know formal learning or education, but also a place for channeling local wisdom values that can be learned by students in the classroom. The philosophy of the Ro'A Dun Kare Taden in Sikka community, can be a reference for local wisdom-based learning, by becoming additional material that is taught on environmental themes, natural sciences and socio-cultural sciences.

\section{Conclusion}

The development of the times has always been followed by changes in life style, perspective, style, character, and human behavior patterns. At the primary school level, teachers play a very important role in the effort to pass on local cultural values to students. As the foundation for the values and character of the early formal education, a teacher needs to be astute and concerned about the various global changes in the world today. Likewise, efforts to introduce, understand, and teach students to love and care for their environment can be done by conducting a comparative study of the values of local wisdom that can be applied in learning activities. Ro'A Dun Kare Taden is one of the philosophies that should be brought to life at all times so that the younger generation, who are elementary school students, can build 
a commitment from an early age to protect and care for forest ecosystems and their environment for their sustainability.

Based on the research results and conclusions above, the authors recommend the following:

a. To the holders of public policies and public figures, if they carry out a comprehensive consolidation of roles for the implementation of problem management that is accurate, ideal and can be accounted for. Regarding the application of the philosophy of Ro'A Dun Kare Taden, both the government (stakeholders) and community leaders should not stop carrying out ecological campaigns related to forest protection as a resource for the younger generation;

b. The school, especially teachers, should always apply learning patterns that accommodate various local cultural values, so as to build love for students and not be lost in the changing times;

c. This research is the author's initial attempt so that the role of the world of basic education remains important in the realm of inheriting fundamental values from the local culture of each region. Likewise, this research opens space for further research related to the same issue, or related to the role of education in teaching students the urgency of local cultural wisdom.

\section{References}

[1] Afandi, R: Integrasi Pendidikan Lingkungan Hidup Melalui Pembelajaran IPS di Sekolah Dasar Sebagai Alternatif Menciptakan Sekolah Hijau, Pedagog. Jurnal Pendidik. pp. 98-108 (2013)

[2] Akhmar, Syariffudin: Mengungkap Kearifan Lingkungan Sulawesi Selatan. PPLH Regional Sulawesi, Maluku dan Papua, Masagena Press, Kementerian Negara Lingkungan Hidup $\operatorname{RI}(2007)$

[3] Asmani, J.M: Pendidikan Berbasis Keunggulan Lokal, Diva Press, Yogyakarta(2012)

[4] Daeng, H.J: Manusia, Kebudayaan dan Lingkungan Tinjauan Antropologis, PustakaPelajar, Yogyakarta(2008)

[5] Dako,F.X. R.H. Purwanto, L.R.W. Farida, Sumardi:Kerusakan Antropogenik Kawasan Hutan Lindung Mutis Timau dan Upaya Penanggulangannya di Pulau Timor Bagian Barat, Journal Natural Resource Environment Management. pp. 437-455 (2019)

[6] Gunawan, R. E. Digdoyo, A. Subarkah: Budaya Kearifan Lokal Dalam Tata Kelola Dan Pengembangan Lingkungan Kota, Jurnal Sejarah dan Budaya. pp. 207-214 (2014)

[7] Keraf, S.A: Etika Lingkungan, Buku Kompas, Jakarta (2022)

[8] Miles, Huberman: Analisis Data Kualitatif Buku Sumber Tentang Metode-MetodeBaru. Terjemahan Tjetjep Rohendi Rohidi, Universitas Indonesia, Jakarta (2009)

[9] Mansur. S: Kearifan Lokal Kemalik Suku Sasak Untuk Menjaga Kelestarian Lingkungan Hidup Dusun Sade, Gema Wiralodra. pp 183-193 (2018)

[10] Moleong, L.J: Metodelogi Penelitian Kualitatif, Remaja Rosdakarya, Bandung (2009

[11] Mukthar, Soemarno, H. Klowon, Pengelolaan Program Hutan Kemasyarakatan Berbasis Kearifan Lokal : Studi Kasus Di Kawasan, Wacana Jurnal Sosial dan Humaniora. pp 132-151 (2020)

[12] Pasya, G.K: Perlindungan Hutan Melalui Kearifan Lokal, Jurnal Geografi(2016)

[13] Samosir: Hukum Adat Indonesia, Eksistensi dalam Dinamika Perkembangan Hukum di Indonesia, Nuansa Aulia, Bandung (2013)

[14] Sriyanto: Kondisi Lingkungan Hidup Di Jawa Tengah dan Prospek Pembangunan Ke Depan, Jurnal Geografi. pp 107-113 (2007)

[15] Suhartini: Menggali Kearifan Lokal Nusantara: Sebuah Kajian Filsafati, Jurnal Filsafat. (2004)

[16] Syaprillah, A.. S. Sapriani: Pengelolaan Hutan Lindung Kota Tarakan Dalam Perspektif Pembangunan Berkelanjutan, Jurnal Ilmu Hukum. pp. 598-618 (2014) 
[17] Undang-undang Republik Indonesia Nomor 32 Tahun 2009 Tentang Perlindungan dan Pengelolaan Lingkungan Hidup, Sekretariat Negara Republik Indonesia, Jakarta (2009)

[18] Wahono, F: Pangan, Kearifan Lokal dan Keanekaragaman Hayati, Cindelaras Pustaka Rakyat Cerdas, Yogyakarta (2005)

[19] Wardhani, N.W: Pembelajaran Nilai-Nilai Kearifan Lokal Sebagai Penguat Karakter Bangsa Melalui Pendidikan Informal, Jurnal Penelitian Pendidikan. pp. 56-66 (2013)

[20] Wibowo, D.A: Perlindungan Hukum Terhadap Benda Cagar Budaya Studi Kasus di Pengadilan Negeri Surakarta, Jurisprudence (2014)

[21] Widoyoko, E.P: Penilaian Hasil Pembelajaran di Sekolah, Pustaka Pelajar, Yogyakarta (2018) 